\title{
Transmission rate of two Polish Tomato torrado virus isolates through tomato seeds
}

\author{
Henryk Pospieszny ${ }^{1} \cdot$ Natasza Borodynko-Filas ${ }^{1} \cdot$ Beata Hasiów-Jaroszewska ${ }^{1}$ Natalia Rymelska ${ }^{1}$. \\ Santiago F. Elena ${ }^{2,3}$
}

Received: 13 June 2018 / Accepted: 6 August 2018 / Published online: 2 November 2018

(C) The Author(s) 2018

\begin{abstract}
Efficient dispersion of Tomato torrado virus (ToTV), an emerging virus affecting tomato crops worldwide, is linked to its principal vectors, Bemisia tabaci and Trialeurodes vaporariorum. To evaluate whether ToTV can be seed-transmitted, we collected seeds from tomato varieties Beta Lux, Grace and Money Maker that had been mechanically inoculated with two ToTV isolates; seedlings were grown in an insect-proof glasshouse, then tested for ToTV by immunocapture-qRT-PCR. Among 17,985 plants, 69 were ToTV-positive ( $0.38 \%$ overall vertical transmission). Bioassays using indicator plants confirmed the presence of infectious virus in the seedlings. This is the first report of tomato seed transmission of ToTV.
\end{abstract}

Keywords ToTV $\cdot$ Tomato $\cdot$ Seed transmission $\cdot$ IC-qRT-PCR

\section{Introduction}

In 2001, necrosis on leaves and fruits of greenhouse tomato plants (Solanum lycopersicum) in the Murcia region of Spain were observed, seriously affecting tomato production. Local producers called the disease "torrado", which means burnt or roasted (Alfaro-Fernández et al. 2006). At the same time, similar symptoms were observed on greenhouse tomatoes in Poland and associated with the presence of a whitefly (Trialeurodes vaporariorum) population (Pospieszny 2005). In 2007, in tomato samples from the Murcia region, a new virus named Tomato torrado virus (ToTV) was characterized (Verbeek et al. 2007). Apart from reports of the virus in Spain and Poland (Alfaro-Fernández et al. 2008; Pospieszny et al. 2007; Verbeek et al. 2007), a natural ToTV infection has also been described on tomatoes in the Canary Islands (Alfaro-Fernández et al. 2008), France (Verdin et al.

Henryk Pospieszny

H.Pospieszny@iorpib.poznan.pl

1 Department of Virology and Bacteriology, Institute of Plant Protection-National Research Institute, Wł. Węgorka 20, 60-318 Poznań, Poland

2 Instituto de Biología Integrativa de Sistemas, Consejo Superior de Investigaciones Científicas-Universitat de València, Valencia, Spain

3 The Santa Fe Institute, Santa Fe, NM, USA
2009), Hungary (Alfaro-Fernández et al. 2009), Panama (Herrera-Vásquez et al. 2009), Australia (Gambley et al. 2010), Italy (Davino et al. 2010), Colombia (Verbeek and Dullemans 2012), and South Africa (Moodley et al. 2016). The virus particles are isometric with a diameter of approximately $28 \mathrm{~nm}$ and often grouped in crystalline aggregates (Pospieszny et al. 2007; Zielińska et al. 2012). The viral genome consists of two (+)ssRNA molecules of $7793 \mathrm{nt}$ (RNA1) and 5389 nt (RNA2) (Verbeek et al. 2007). A study of ToTV accumulation in the infected plants revealed that ToTV titer was very low, reaching its maximum in the early stages of infection and declining rapidly thereafter (Gómez et al. 2010). This dynamic could have a strong effect on viral transmission via plant sap. Indeed, ToTV is poorly transmitted mechanically to tested plant species in controlled conditions (Pospieszny et al. 2007, 2010), but efficient dispersion has been linked to the occurrence of its principal vectors, Bemisia tabaci and Trialeurodes vaporariorum. The question of how ToTV is spread over long distances, however, remains unanswered. A potential role of contaminated seeds has been suggested because even a low transmission rate can be an important mechanism of viral dissemination. In previous reports that found no evidence of seed transmission, low numbers of seeds were tested, and other factors such as the limited accumulation of the virus in infected plants were not considered (Gambley et al. 2010). Therefore, the 
present study was designed to evaluate whether ToTV can be transmitted through tomato seeds.

\section{Materials and methods}

\section{Seed harvest and cleaning}

The experiments were conducted during 2011-2013 using tomato varieties Beta Lux, Grace and Money Maker and isolates ToTV-Wal and ToTV-Kra. ToTV-Wal was isolated from greenhouse tomato plants in 2003 in the Wielkopolska Province of Poland and ToTV-Kra isolate was obtained in 2007 in the Mazowieckie Province of Poland.

The isolates differ in their biological properties. ToTVWal induces more severe symptoms than ToTV-Kra on the majority of tomato varieties and other plant species. Tomato plants that were used for seed production were mechanically inoculated with sap from infected ToTV plants, kept in a greenhouse at $20-25^{\circ} \mathrm{C}$ with a $14-\mathrm{h}$ photoperiod, then monitored for symptom development. Plants with the typical leaf necrosis of ToTV were selected for seed production and tested for the presence of ToTV by RT-PCR. Total RNA was extracted using the RNeasy Plant Mini Kit (Qiagen, Hilden, Germany), according to the manufacturer's instructions. RT-PCR was performed using a Transcriptor One-Step RT-PCR Kit (Roche, Basel, Switzerland) and TR1F/TR1R primers (Pospieszny et al. 2007). In 2011, experiments were conducted on Beta Lux tomatoes with isolate ToTV-Kra. In 2012, Grace and Money Maker and the isolates ToTV-Kra and ToTV-Wal were used. Ripe fruits were harvested at the beginning, middle, and end of July. The seeds were manually separated from the tomato pulp and cleaned. Fruits were cut in half, and all seeds were removed, transferred to a glass container and left to ferment for $24 \mathrm{~h}$ at $25-27{ }^{\circ} \mathrm{C}$. Next, seeds were put in a sieve, washed with water and dried at room temperature. The seeds were stored by variety in separate paper bags at $5{ }^{\circ} \mathrm{C}$ for $4-5$ weeks.

\section{Seed transmission}

Seeds were disinfected in 10\% (w/v) aqueous trisodium phosphate solution for $2 \mathrm{~h}$ to minimize the possibility that any virus present was not simply the result of virus contamination on the seed coat, but rather the result of an embryonic infection (Ling 2008). Seeds were sown individually in pots with sterile soil 4-5 weeks after the seeds were harvested. Seedlings were grown in closed, monitored, insectfree greenhouse compartments equipped with insect-proof screens. After each experiment, they were closed and disinfected. After 5-6 weeks, young leaf samples were taken from each plant and pooled into batches of 5 or 10 plants. All pooled samples were analyzed for the presence of ToTV by IC-qRT-PCR using a virus-specific polyclonal antibody developed at the Institute of Plant Protection, Poznan, Poland (Pospieszny et al. 2010). The plants from positive batches were also individually tested by RT-PCR for the presence of ToTV as described above. For verifying the infectivity of the virus, fragments of the ToTV-positive seedlings were ground in $0.05 \mathrm{M}$ phosphate buffer $\left(8.7 \mathrm{~g} / \mathrm{l}\right.$ of $\mathrm{KH}_{2} \mathrm{PO}_{4} ; \mathrm{pH}$ 7.2) at a ratio of $1: 5(w / v)$. The sap was then used to gently rub leaves of Nicotiana benthamiana (3-4-leaf stage) and $S$. lycopersicum var. Beta Lux (2-3-leaf stage) seedlings that had been lightly dusted with carborundum (300 mesh grit powder). Plants were maintained in an insect-free greenhouse at $23-26^{\circ} \mathrm{C}$ with a 14 -h light period. Symptoms were evaluated 3 weeks after inoculation, and the presence of ToTV in plants was verified by RT-PCR.

\section{IC-qRT-PCR assay}

Wells $(0.2 \mathrm{ml})$ of a microtiter plate (Abgene, Thermo Fisher Scientific, Waltham, MA, USA) were pre-coated with $25 \mu \mathrm{l}$ of $2.0 \mu \mathrm{g} / \mathrm{ml}$ purified anti-ToTV antibody in ELISA coating buffer and incubated $1 \mathrm{~h}$ at $37^{\circ} \mathrm{C}$. The plate was washed three times with phosphate buffer (Clark and Adams 1977). Tomato tissue was ground in a homogenizer (BioReba, Reinach, Switzerland) with an extraction buffer $(1: 10 \mathrm{w} / \mathrm{v})$ (Loewe, Sauerlach, Germany), and similar extracts from ToTV mechanically inoculated tomato plants were used as the positive control and from healthy tomato plants as the negative control. Next, $25 \mu \mathrm{l}$ of the extract was loaded in each anti-ToTV, antibody-coated well and incubated at $37^{\circ} \mathrm{C}$ for $2 \mathrm{~h}$ for trapping ToTV particles. After a thorough washing with phosphate buffer (Loewe, Sauerlach, Germany), the treated wells were subjected to qRT-PCR. For each reaction, $1 \mu \mathrm{l}$ each of primer ToTVrealF 5'-AAGGACGAAGAG CGACTGT-3' (corresponding to nt 3684-3702 of RNA2 Wal'03 isolate, EU563947.1) and ToTVrealR 5'-GTGGTG TATTCAAGACTTC-3' (corresponding to nt 3814-3831 of RNA2 Wal'03 isolate, EU563947.1) (in $10 \mu \mathrm{M}$ stock) was added to $12.5 \mu$ l Brilliant II SYBR Green qRT-PCR, $0.375 \mu$ diluted reference dye and $0.5 \mu l$ enzyme (Agilent Technologies, Santa Clara, CA, USA). The thermal cycling process and fluorescence signal detection were carried out with the Mx3005P real-time PCR system (Agilent Technologies, Santa Clara, CA, USA). The cycling parameters were reverse transcription for $30 \mathrm{~min}$ at $50{ }^{\circ} \mathrm{C}$, activation of polymerase for $10 \mathrm{~min}$ at $95^{\circ} \mathrm{C}$, followed by 40 cycles of $30 \mathrm{~s}$ for denaturation at $95^{\circ} \mathrm{C}$, annealing at $52^{\circ} \mathrm{C}$ for $30 \mathrm{~s}$, and extension at $72{ }^{\circ} \mathrm{C}$ for $30 \mathrm{~s}$. Two replications of each sample were done. Samples with $\mathrm{C}_{\mathrm{q}}$ (quantification cycle) values below 35 were run in a $1 \%$ agarose gel at $80 \mathrm{~V}$ for $1 \mathrm{~h}$ and stained with Midori Green (Nippongenetics, Düren, Germany) and viewed with a UV transilluminator. The obtained products of ca. $147 \mathrm{bp}$ were purified from the gel using a NucleoSpin 
Gel and PCR Clean-up kit (Macherey-Nagel, Düren, Germany), then ligated into the pGEM-T easy vector (Promega, Madison, WI, USA) and sequenced. The obtained sequences were compared with the sequence of the respective tested isolates and others retrieved from the GenBank database.

\section{Statistical methods}

The frequency of infected plants per batch, $p$, was fitted to the following log-linear generalized linear model (GLM) that incorporates a binomial distribution of probabilities and a logit link function (chosen among a set of models on the basis of the lowest Bayesian information criterion):

$\operatorname{logit}\left(\hat{p}_{i j}\right)=\pi+V_{i}+T_{j}+\varepsilon_{i j}$,

where $\pi$ is the grand mean value for the frequency of vertical seed transmission, $V$ accounts for the ToTV isolate $(i=\mathrm{Kra}$ or Wal), $T$ for the tomato variety ( $j=$ Beta Lux, Grace or Money Maker), and the error term $\varepsilon_{i j}$ is estimated from the differences among batches of tomato variety $j$ infected with ToTV isolate $i$. Given the unbalanced experimental design (not all combinations of ToTV isolates and tomato varieties were evaluated as explained in the Results), the model cannot incorporate and evaluate the interaction term $V \times T$, and thus only main effects were considered.

To explore the association between presence of symptoms in fruits and seed transmission efficiency in Grace tomatoes, we fitted the frequency of infected plants, $p$, to a log-linear model with the following equation:

$\operatorname{logit}\left(\hat{p}_{i j}\right)=\pi+V_{i}+S_{j}+(V \times S)_{i j}+\varepsilon_{i j}$,

where $S$ is the factor accounting for presence or absence of symptoms and $V \times S$ is the interaction term.

The significance of the factors in the two models was evaluated by means of likelihood-ratio tests that asymptotically follow a $\chi^{2}$ probability function. Seed transmission rates are reported as percentages with confidence intervals representing $\pm 1 \mathrm{SD}$ and were estimated by maximum likelihood from the log-linear model. All statistical analyses were done with SPSS v24 (IBM, Armonk, NY, USA).

\section{Results}

The results of the seed transmission experiments are summarized in Fig. 1 and in Table 1. In 2011, among 5,400 seedlings of the Beta Lux variety, 17 were infected with ToTV-Kra, indicating an average transmission of $0.32 \% \pm$ 0.08 . The actual rate differed among seed batches and varied from 0 to $0.67 \%$. Plants of the Beta Lux variety infected with ToTV-Wal displayed very severe necrosis and produced a

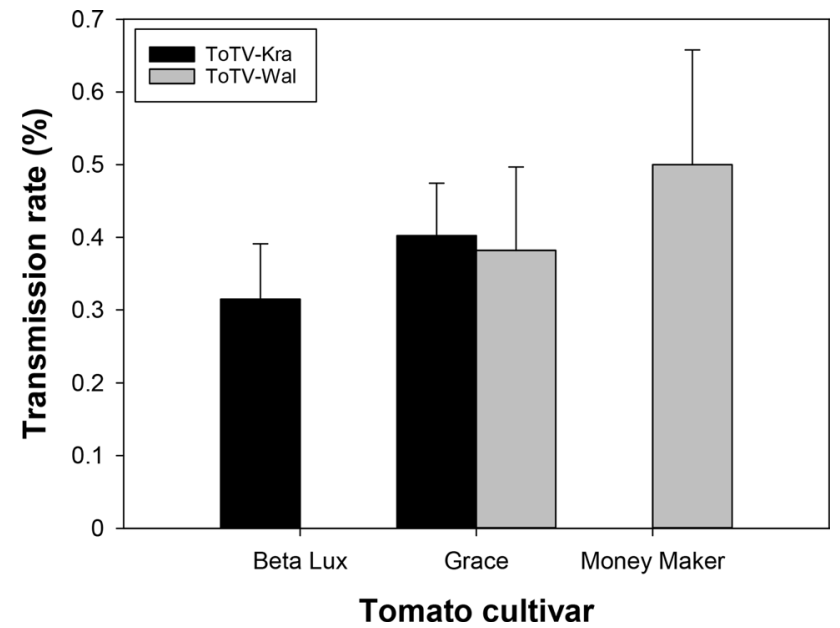

Fig. 1 Mean percentage transmission of two isolates of ToTV via seed to three tomato varieties. Error bars represent $\pm 1 \mathrm{SD}$

limited number of fruits, and therefore could not be used in seed transmission experiments. In 2012, 7705 plants of variety Grace were tested, and seed transmission rates varied from 0 to $0.864 \%$, depending on the seed batch used. Overall, 31 plants were infected with ToTV-Kra, indicating an average seed transmission rate of $0.40 \% \pm 0.07$. Among 2880 Grace plants inoculated with ToTV-Wal, 11 were infected, indicating a seed transmission rate of $0.382 \% \pm$ 0.12 . The rate of ToTV-Wal seed transmission in this variety also varied from 0 to $0.71 \%$ among seed batches. Finally, among the 2,000 seeds harvested from Money Maker plants infected with ToTV-Wal, only 10 plants were positive (average transmission rate of $0.5 \% \pm 0.16$. The rate of ToTVWal transmission in Money Maker varied from 0 to $0.714 \%$ across seed batches. Money Maker plants used for seeds production were not efficiently infected with ToTV-Kra, and not enough seeds were produced for seed transmission experiments. The period of harvesting the fruits did not have significant impact on virus transmission. The fit of all these data to the log-linear model that is described by Eq. 1 showed no significant differences among ToTV isolates $\left(\chi^{2}=0.022,1 \mathrm{df}, P=0.881\right)$ or tomato varieties $\left(\chi^{2}=1.056\right.$, $2 \mathrm{df}, P=0.590)$ in their seed transmission rates. However, the grand mean seed transmission rate $(\pi)$ is highly significant $\left(\chi^{2}=16,529.326,1 \mathrm{df}, P<0.001\right)$, thus indicating that despite the low seed transmission rates estimated, the grand mean value was significantly greater than zero and equal to $0.395 \% \pm 0.057$, thus supporting significant transmission of ToTV by tomato seeds.

The sequencing of 147-bp amplicons encompassing the coat protein Vp23 region of ToTV RNA2 obtained in the IC-qRT-PCR revealed $100 \%$ identity with the sequences of the ToTV isolates used in this study and approximately $99 \%$ with other isolates deposited in GenBank (PRI-ToTV0301 
Table 1 Transmission of two ToTV isolates through seeds of three tomato varieties

\begin{tabular}{|c|c|c|c|c|c|}
\hline ToTV isolate/tomato variety (Year) & Batches $^{\mathrm{a}}$ & $\begin{array}{l}\text { No. of } \\
\text { tested } \\
\text { seeds }\end{array}$ & $\begin{array}{l}\text { No. of } \\
\text { positive } \\
\text { seeds }\end{array}$ & Transmission (\%) & $\begin{array}{l}\mathrm{C}_{\mathrm{q}} \text { values } \\
\text { of positive } \\
\text { samples }^{\mathrm{b}}\end{array}$ \\
\hline \multirow[t]{12}{*}{ ToTV-Kra/Beta Lux (2011) } & 1 & 540 & 1 & 0.185 & \multirow[t]{12}{*}{$30.47-33.21$} \\
\hline & 2 & 530 & 2 & 0.377 & \\
\hline & 3 & 654 & 2 & 0.306 & \\
\hline & 4 & 513 & 2 & 0.390 & \\
\hline & 5 & 600 & 4 & 0.667 & \\
\hline & 6 & 370 & 0 & 0.000 & \\
\hline & 7 & 396 & 1 & 0.253 & \\
\hline & 8 & 420 & 1 & 0.238 & \\
\hline & 9 & 583 & 1 & 0.172 & \\
\hline & 10 & 434 & 2 & 0.461 & \\
\hline & 11 & 360 & 1 & 0.278 & \\
\hline & 11 & 5400 & 17 & 0.315 & \\
\hline \multirow[t]{20}{*}{ ToTV-Kra/Grace (2012) } & 1 & 443 & 1 & 0.226 & \multirow[t]{20}{*}{$31.02-34.19$} \\
\hline & 2 & 417 & 2 & 0.480 & \\
\hline & 3 & 381 & 1 & 0.262 & \\
\hline & 4 & 359 & 1 & 0.279 & \\
\hline & 5 & 320 & 1 & 0.313 & \\
\hline & 6 & 446 & 2 & 0.448 & \\
\hline & 7 & 348 & 1 & 0.287 & \\
\hline & 8 & 416 & 1 & 0.240 & \\
\hline & 9 & 454 & 3 & 0.661 & \\
\hline & 10 & 416 & 1 & 0.240 & \\
\hline & 11 & 442 & 3 & 0.679 & \\
\hline & 12 & 450 & 2 & 0.444 & \\
\hline & 13 & 440 & 2 & 0.455 & \\
\hline & 14 & 420 & 2 & 0.476 & \\
\hline & 15 & 418 & 1 & 0.239 & \\
\hline & 16 & 463 & 4 & 0.864 & \\
\hline & 17 & 427 & 1 & 0.234 & \\
\hline & 18 & 390 & 2 & 0.513 & \\
\hline & 19 & 255 & 0 & 0.000 & \\
\hline & 19 & 7705 & 31 & 0.402 & \\
\hline \multirow[t]{9}{*}{ ToTV-Wal/ Grace (2012) } & 1 & 360 & 2 & 0.556 & \multirow[t]{9}{*}{$31.36-33.58$} \\
\hline & 2 & 420 & 3 & 0.714 & \\
\hline & 3 & 340 & 1 & 0.294 & \\
\hline & 4 & 280 & 0 & 0.000 & \\
\hline & 5 & 410 & 1 & 0.244 & \\
\hline & 6 & 390 & 2 & 0.513 & \\
\hline & 7 & 380 & 1 & 0.263 & \\
\hline & 8 & 300 & 1 & 0.333 & \\
\hline & 8 & 2880 & 11 & 0.382 & \\
\hline \multirow[t]{7}{*}{ ToTV-Wal/Money Maker (2012) } & 1 & 310 & 2 & 0.645 & \multirow[t]{7}{*}{$31.55-34.26$} \\
\hline & 2 & 420 & 3 & 0.714 & \\
\hline & 3 & 380 & 2 & 0.526 & \\
\hline & 4 & 350 & 2 & 0.571 & \\
\hline & 5 & 300 & 1 & 0.333 & \\
\hline & 6 & 240 & 0 & 0.000 & \\
\hline & 6 & 2000 & 10 & 0.5 & \\
\hline
\end{tabular}

${ }^{a}$ Each batch contained seeds derived from different plants

${ }^{b}$ Plants were tested for virus using IC-qRT-PCR isolate [accession DQ388880] and T75 isolate [accession KX132809.1]). For the tested samples, virus-specific products were only amplified from the positive controls and plants infected from seeds. The positive controls had $\mathrm{C}_{\mathrm{q}}$ values of 21.31-23.47, whereas the samples from infected seeds had $\mathrm{C}_{\mathrm{q}}$ values of 30.47-34.26. Dissociation curve analyses indicated the presence of single amplicons with a melting temperature $\left(T_{\mathrm{m}}\right)$ of $81{ }^{\circ} \mathrm{C}$. None of the ToTV-positive seedlings had symptoms of virus infection; however, ToTV was confirmed in $80 \%$ of the plants assayed. 
Motivated by this last observation, we sought to explore whether seed transmission efficiency was related to the presence or absence of symptoms in tomato fruits. Hence, using seeds isolated from symptomatic and asymptomatic fruits from plants of the Grace variety in transmission tests of ToTV-Kra, we detected 21 positive seedlings among 1,960 symptomatic plants tested $(1.071 \% \pm 0.233)$ and only 2 positives among 1,725 asymptomatic plants tested $(0.116 \% \pm 0.082)$. Likewise, for ToTV-Wal, seeds from asymptomatic Grace fruits had a very low vertical transmission rate ( 1 of 1,120 plants tested; $0.089 \% \pm 0.089)$, while transmission from symptomatic fruits was almost 10 times higher ( 7 positive cases of 835 tested plants: $0.838 \%$ $\pm 0.316)$. Results of this study are shown in Fig. 2. For better insights into the significance of these data, we fitted them to Eq. 2. As before, the grand mean value estimated was significantly larger than zero $\left(\chi^{2}=6,849.708,1 \mathrm{df}\right.$, $P<0.001$ ), confirming our previous conclusion that ToTV can be transmitted via seeds at a low though significant rate. Also consistent with the results, differences between the two ToTV isolates were not significant $\left(\chi^{2}=0.159,1\right.$ df, $P=0.690$ ), nor was their interaction with the symptomatology of the parental plants $\left(\chi^{2}=0.000,1 \mathrm{df}, P=0.992\right)$. By contrast, and more interestingly, we found highly significant differences in the rates of vertical transmission for seeds from symptomatic and asymptomatic plants $\left(\chi^{2}=19.409,1 \mathrm{df}, P<0.001\right)$, being the seed transmission rate 9.315 times higher for symptomatic fruits than for asymptomatic ones. Therefore, we conclude that seed transmission strongly depends on whether tomato fruits show symptoms or not, which probably depends on the level of virus accumulation.

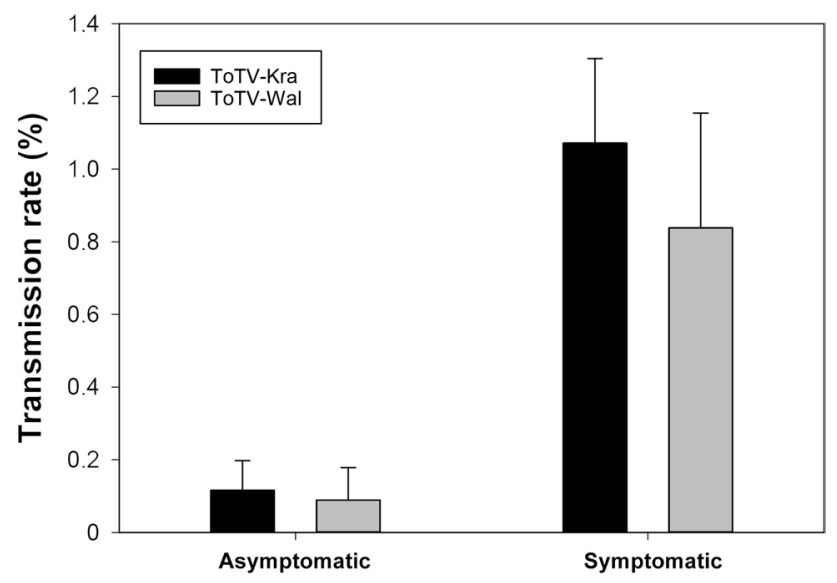

Fig. 2 Mean percentage transmission of two isolates of ToTV via seeds from symptomatic or asymptomatic fruits. Error bars represent $\pm 1 \mathrm{SD}$

\section{Discussion}

Investigating transmission modes and efficiency for a virus is extremely important to understand the factors contributing to the epidemiology of a viral disease ( $\mathrm{Li}$ et al. 2016). Transmission of a virus through seeds can play a significant role in the epidemiology of crop pathogens, which are often secondarily disseminated via insect vectors so that even extremely low frequencies of seed transmission can result in severe epidemics (Simmons and Munkvold 2014). ToTV is rather poorly transmitted mechanically (Pospieszny et al. 2010), which could be correlated with the low stability of the virus in plant sap and low accumulation of ToTV in plants.

Moreover, ultrastructural studies revealed that most of the ToTV particles were packed in crystals and aggregates of different types in plant cells (Alfaro-Fernández et al. 2010; Pospieszny et al. 2007; Zielińska et al. 2012). This type of aggregated particles is distributed in different cell compartments, which might greatly impact infectivity and movement of the viral particles to generative organs. On the other hand, ToTV is efficiently transmitted by whiteflies (Amari et al. 2008; Pospieszny et al. 2007) in a semi-persistent manner (Verbeek et al. 2013). Nevertheless, none of these modes of ToTV transmission seem to be responsible for the spread of the virus over long distances (across continents). In the present study using more than 17,000 tomato seedlings, ToTV clearly was transmitted to the next generation via seeds at measurable frequencies. Even at the low incidence of vertical transmission of ToTV in the progeny seedlings, seed transmission can be very important for long-distance virus dissemination. Dispersal of seed-borne particles through the international seed trade can thus explain the recent rapid dispersion of ToTV worldwide. Its further spread locally will be strongly correlated with the presence of very effective whitefly vectors. The significantly low seed transmission rate $(0.001 \%)$ of the Lettuce mosaic virus has been shown to be sufficient for the spread of the virus by aphids (Johansen et al. 1994). In the case of ToTV, plants grown from infected seeds are probably not good enough sources of the virus for mechanical spreading but are sufficient for the spread of the virus by whiteflies. It is worth mentioning that between one and three virus particles have been reported to be sufficient for the transmission of viruses by aphids (Betancourt et al. 2008; Moury et al. 2007). Since the virus concentration in seeds is low, highly sensitive detection methods are required. The techniques based on qPCR assay are highly sensitive and reported to be capable of detecting approximately 17 copies of viral RNA (Hasiów-Jaroszewska et al. 2015). In this study, the IC-qRT-PCR assay was developed to simplify the post-amplification analysis, increase the assay sensitivity and specificity and decrease the time for sample examination. 
The very long delay before the appearance of symptoms after infection via seed transmission, or even the lack of symptoms, indicate the impossibility of eradicating these sources of virus by visual means. The lack of symptoms on ToTV-infected seedlings is not unusual for viruses. Many plant viruses, Pepino mosaic virus on tomato (Hanssen et al. 2010), Cucumber mosaic virus (CMV) on chickpea (Stellaria media) and on pepper (Ali and Kobayashi 2010; Gallitelli 2000) and Zucchini yellow mosaic virus on Cucurbita pepo subsp. texana (Simmons et al. 2011) have been reported to produce asymptomatic plants from infected seeds. Asymptomatic infection is a critical problem for quarantine inspection for ToTV. Healthy-appearing seedlings might be overlooked and thus be involved in spreading the virus, especially through grafting.

While ToTV transmission through tomato seeds seems to be clear, interestingly, the transmission rate was nine times higher via seeds from symptomatic fruits than those from asymptomatic fruits. More severe symptoms are usually the result of higher virus titer. The high transmission rate may also indicate different distributions of virus particles in fruits produced by the same plant at different post-inoculation times. In addition, both isolates were transmitted via seeds from the different varieties at very similar rates. Although further research is required to estimate the impact of the virus genotype and the host of viral transmission through seeds, the present study highlights the risk of using seeds from ToTV-infected plants and the potential for seed transmission to contribute to further spread of ToTV.

Acknowledgements This study was supported by project N N310 732040 from National Science Centre of Poland. Work in Valencia was supported by grant BFU2015-65037-P from Spain's Agencia Estatal de Investigación - FEDER.

\section{Compliance with ethical standards}

Human and animal rights This article does not contain any studies with human participants or animal performed by any of the author.

Conflict of interest The authors declare that they have no conflict of interest.

Open Access This article is distributed under the terms of the Creative Commons Attribution 4.0 International License (http://creativeco mmons.org/licenses/by/4.0/), which permits unrestricted use, distribution, and reproduction in any medium, provided you give appropriate credit to the original author(s) and the source, provide a link to the Creative Commons license, and indicate if changes were made.

\section{References}

Alfaro-Fernández A, Córdoba-Sellés MC, Cebrián-Micó MC, Font I, Juárez M, Medina V, Lacasa A, Sánchez-Navarro JA, Pallás V, Jordá-Gutiérrez C (2006) Nacrosis del tomate: "torrao" o "cribado" (in Spanish). Bol San Veg Plagas 32:545-562

Alfaro-Fernández A, Córdoba-Sellés C, Cebrián MC, Herrera-Vásquez JA, Sánchez-Navarro JA, Juárez M, Espino A, Martin R, Jordá C (2008) First report of Tomato torrado virus on weed hosts in Spain. Plant Dis 92:831

Alfaro-Fernández A, Bese G, Córdoba-Sellés C, Cebrián MC, Herrera-Vásquez JA, Forray A, Jordá C (2009) First report of tomato torrado virus infecting tomato in Hungary. Plant Dis 93:554

Alfaro-Fernández A, Medina V, Córdoba-Sellés MC, Font MI, Jornet J, Cebrián MC, Jordá C (2010) Ultrastructural aspects of tomato leaves infected by Tomato torrado virus (ToTV) and co-infected by other viruses. Plant Pathol 59:231-239

Ali A, Kobayashi M (2010) Seed transmission of Cucumber mosaic virus in pepper. J Virol Methods 163:234-237

Amari K, Gonzales-Ibeas D, Gómez P, Sempere RN, Sánchez-Pina MA, Aranda MA, Díaz-Pendón JA, Navas-Castillo J, Blanca J, Herandez-Gallardo MD, Anastasio G (2008) Tomato torrado virus is transmitted by Bemisia tabaci and infects pepper and eggplant in addition to tomato. Plant Dis 92:1139

Betancourt M, Fereres A, Fraile A, García-Arenal F (2008) Estimation of the effective number of founders that initiate an infection after aphid transmission of a multipartite plant virus. J Virol $82: 12416-12421$

Clark MF, Adams AN (1977) Characteristics of the microplate method of enzyme-linked immunosorbent assay for the detection of plant viruses. J Gen Virol 34:475-483

Davino S, Bivona L, Iacono G, Davino M (2010) First report of Tomato torrado virus infecting tomato in Italy. Plant Dis 94:1172

Gallitelli D (2000) The ecology of Cucumber mosaic virus and sustainable agriculture. Virus Res 71:9-21

Gambley CF, Thomas JE, Persley DM, Hall BH (2010) First report of Tomato torrado virus on tomato from Australia. Plant Dis 94:486

Gómez P, Sempere RN, Amari K, Gómez-Aix C, Aranda MA (2010) Epidemics of Tomato torrado virus, Pepino mosaic virus and Tomato chlorosis virus in tomato crops: Do mixed infections contribute to torrado disease epidemiology? Ann Appl Biol 156:401-410

Hanssen I, Mumford R, Blystad DR, Cotrez I, Hasiów-Jaroszewska B, Hristova D, Pagán I, Pereira AM, Peters J, Pospieszny H, Ravnikar M, Stijger I, Tomassoli L, Varveri C, van der Vlugt R, Nielsen SL (2010) Seed transmission of Pepino mosaic virus in tomato. Eur J Plant Pathol 126:145-152

Hasiów-Jaroszewska B, Rymelska N, Borodynko N (2015) LNA probebased assay for the detection of Tomato black ring virus isolates. Mol Cell Probes 29:78-80

Herrera-Vásquez JA, Alfaro-Fernández A, Córdoba-Sallés MC, Cebrián MC, Font MI, Jordá C (2009) First report of Tomato torrado virus infecting tomato in single and mixed infections with Cucumber mosaic virus in Panama. Plant Dis 93:198

Johansen E, Edwards MC, Hampton RO (1994) Seed transmission of viruses: current perspectives. Annu Rev Phytopathol 32:363-386

Li JX, Liu SS, Gu QS (2016) Transmission efficiency of Cucumber green mottle mosaic virus via seeds, soil, pruning and irrigation water. J Phytopathol 164:300-309

Ling KS (2008) Pepino mosaic virus on tomato seed: Virus location and mechanical transmission. Plant Dis 92:1701-1705

Moodley V, Gubba A, Mafongoya PL (2016) First report of Tomato torrado virus on tomato (Solanum lycopersicum) in South Africa. Plant Dis 100:231 
Moury B, Fabre F, Senoussi R (2007) Estimation of the number of virus particles transmitted by an insect vector. Proc Natl Acad Sci USA 104:17891-17896

Pospieszny H (2005) Preliminary study on the spherical virus transmitted by greenhouse whitefly (Trialeurodes vaporariorum). In: 2nd Joint Conference of the inter working groups on legume (IWGLV) and Vegetable Viruses (IWGVV), Fort Lauderdale, FL, USA p 30 (Abstract). University of Florida/IFAS, Gainesville, FL, USA

Pospieszny H, Borodynko N, Obrępalska-Stęplowska A, Hasiów B (2007) The first report of Tomato torrado virus in Poland. Plant Dis 91:1364

Pospieszny H, Budziszewska M, Hasiów-Jaroszewska B, ObrępalskaStęplowska A, Borodynko N (2010) Biological and molecular characterization of Polish isolates of Tomato torrado virus. $\mathrm{J}$ Phytopathol 158:56-62

Simmons HE, Munkvold GP (2014) Seed transmission in the Potyviridae. In: Gullino ML, Munkvold G (eds) Global perspectives on the health of seeds and plant propagation material. Plant pathology in the 21st century, vol 6. Springer, Dordrecht, pp 3-15
Simmons HE, Holmes EC, Gildow FE, Goralczyk MA, Stephenson AG (2011) Experimental verification of seed transmission of Zucchini yellow mosaic virus. Plant Dis 95:751-754

Verbeek M, Dullemans AM (2012) First report of Tomato torrado virus infecting tomato in Colombia. Plant Dis 96:592

Verbeek M, Dullemans AM, van der Heuvel JFJM, Maris PC, van der Vlugt RAA (2007) Identification and characterisation of Tomato torrado virus, a new plant picorna-like virus from tomato. Arch Virol 152:881-890

Verbeek M, van Bekkum PJ, van der Vlugt RAA (2013) Transmission of torradoviruses by their whitefly vectors. In: Proc 12th Inter Symp Plant Virus Epidemiol, Arusha, Tanzania, p 49 (Abstract)

Verdin E, Gognalons P, Wipf-Scheibel C, Bornard I, Ridray G, Schoen L, Lecoq H (2009) First report of Tomato torrado virus in tomato crops in France. Plant Dis 93:1352

Zielińska L, Byczyk J, Rymelska N, Borodynko N, Pospieszny H, Hasiów-Jaroszewska B (2012) Cytopathology of Tomato torrado virus infection in tomato and Nicotiana benthamiana. J Phytopathol 160:685-689 